\title{
Cyproterone Acetate
}

National Cancer Institute

\section{Source}

National Cancer Institute. Cyproterone Acetate. NCI Thesaurus. Code C1059.

The acetate salt of a synthetic steroidal antiandrogen with weak progestational and antineoplastic activities. Cyproterone binds the androgen receptor (AR), thereby preventing androgen-induced receptor activation in target tissues and inhibiting the growth of testosterone-sensitive tumor cells. This agent also exerts progestational agonist properties at the level of the pituitary that reduce luteinizing hormone (LH), resulting in reductions in testicular androgen secretion and serum testosterone levels. Treatment with cyproterone alone results in incomplete suppression of serum testosterone levels. 